\title{
Efficacy of Some Plant Extracts and Biodegradables Wrapping Materials as an Alternative to Fungicides in Increasing Shelf Life Citrus Fruits
}

\author{
Rana Ibrahim Khaleel \\ College of Engineering, University of Samarra, Samarra, Iraq \\ Email: ranagh83@yahoo.com
}

How to cite this paper: Khaleel, R.I. (2017) Efficacy of Some Plant Extracts and Biodegradables Wrapping Materials as an Alternative to Fungicides in Increasing Shelf Life Citrus Fruits. Open Journal of Ecology, 7, 621-630.

https://doi.org/10.4236/oje.2017.712042

Received: October 18, 2017

Accepted: November 27, 2017

Published: November 30, 2017

Copyright $\odot 2017$ by author and Scientific Research Publishing Inc. This work is licensed under the Creative Commons Attribution International License (CC BY 4.0).

http://creativecommons.org/licenses/by/4.0/

(c) (i) Open Access

\begin{abstract}
Increasingly global there is an interest to develop a new method by replacing fungicides in packaging fresh fruit by using environment-friendly bio-pesticides, such as use of botanicals or biological control. Five ethanol extracts (concentrations 500 - 5000 ppm) of Cerbera odollam L. (Pong-pong), Capsicum frutescence L. (Chili), Azadirachta indica L. (Neem), Cymbopogon nardus L. (Lemon grass), Zingiber officinale L. (Ginger), were tested for their anti-fungal activity for citrus green mold, black and brown rot, compared with the control fungicide (Guazatine). Efficacy of the selected plant extract in cooperated with biodegradable materials wrappers (Polylactic acid, Pectin and Newspaper) was determined during storage at room temperature $\left( \pm 25^{\circ} \mathrm{C}\right)$ to control fruit-pathogen decay under modified atmosphere packaging (MAP) to increase shelf life and improve the fruit quality. Crude extracts from pong-pong and chili showed fungal inhibition zone at $3000 \mathrm{ppm}$ (c.100\%), and increased shelf life and decreased weigh loss for fruits wrapped and stored at room temperature compared with untreated fruit.
\end{abstract}

\section{Keywords}

Natural Antimicrobial, Plant Extracts, Bio-Pesticides, Biodegradable Materials

\section{Introduction}

The use of synthetic fungicides effects to the environment such as their residue effect can be harmful to human health, besides increased accumulation in water, soil, and fruit besides the elimination of the natural enemies of the involved pathogens [1]. The above scenario has led to the search for safe alternatives to 
synthetic fungicides to control fungal post-harvest rot in citrus to decrease the loss and avoid the negative effects of using fungicides, with the current research focusing on the usage of botanicals. However, there is a growing global concern over the use of synthetic fungicides chemicals on food crops because of the continuous exposure of man to low levels of fungicides residue through his diet. In addition fungicides have an impact on the environment through accumulation in soil and water and effect on biological diversity [2]. These aspects have led to the implementation of more restrictive legislations regarding the maximum residue levels (MRL) of chemical residues in fruits exported particularly to world markets [3]. The application of fungicides often leads to new fungicide-resistant strains as in $P$. digitatum [4]. Keeping in view of these developments, the recent trend in disease management focuses on using natural plant products as all an alternative to fungicides. The natural plant products (botanicals) are generally safer as they degenerate fast thus avoiding residue effect [5]. The bioactive pathogen-inhibiting compounds may include compounds of flavonoids, glycosides, phenols and terpenoids [6]. This study focuses on fruit ripening and the problems related to quality loss during transportation, storage and marketing. The wrapping materials as they are biodegradable and eco-friendly could serve as an alternative to synthetic packaging such as plastic and aluminium foil. Wrapping for the present study is a form of active packaging based on the combination of modified atmosphere packaging used with natural antimicrobial compounds (plant extracts) in cooperation with biodegradable materials in order to improve post-harvest quality in the storage of freshly harvested citrus.

\section{Materials and Methods}

\subsection{Preparing Fruits for the Wrapping}

Fruits were wounded at a depth of $5.0 \mathrm{~mm}$ with a $1.25 \mathrm{~mm}$ diameter needle at the equator and inoculated by spraying with suspension of fungi. The treated fruit were left for an hour after spraying to stabilize the spores on the wound and wrapped with the 3 wrappers polylactic acid, pectin and newspaper. Fungicides and untreated fruits used as control. Each treatment and controls were tested in three replicates using Completely Randomized Design (CRD). Treated fruits were packed and stored in carton boxes and incubated at $25^{\circ} \mathrm{C} \pm 2{ }^{\circ} \mathrm{C}(\mathrm{RH} 65 \%$ $75 \%)$ in the laboratory. Evaluations of the fruit decay, weight loss and shelf life fruit were done after three weeks.

\section{Treatment Spray:}

- $\quad$ spray plant extract (5000 ppm)

- spray fungicides (Guazatin)

- Untreated fruits (Healthy Control) Wrap Process:

- Polylactic acid wrap

- Pectin wrap

- New paper wrap 


\subsection{Fungal Decay}

Fungal decay in stored fruit was evaluated after 21 days under storage conditions. The percentage of infection was determined using scale of $1-5$ with Scale 1 indication no infection and Scale 5 indication high infection (Scale modified from [7]).

\subsection{Weight Loss}

The percentage of weight loss was calculated by determining the progressive reduction in fruit weight during storage after a period of 21 days in relation to the original fresh weight at the beginning of storage [8].

$$
W L(\%)=W L \text { before storage }-W L \text { after storage } / W L \text { before storage } \times 100
$$

\subsection{Statistical Analysis}

Data collected and analysed using analysis of variance (ANOVA). Significant differences between mean values were determined using Duncan's Multiple Range test $(\mathrm{P} \leq 0.05)$. Following ANOVA statistical analysis, which were performed using SPSS version 19-2012 (SPSS Inc., Chicago, USA).

\section{Results and Discussion}

\subsection{Fruit Decay}

ANOVA statistical analysis (Table 1) showed packaging fruits with sprayplant extracts and wrap fruit using (Polylactic acid, Pectin and Newspaper) decreased fungal decay for stored fruit and recorded averages better than the untreated fruit in controlling infection of Green mold, Black rot and Fusarium rot. Generally, Polylactic acid plus Pong-pong, Chili and Neem were better than pectin and newspaper in reducing fungal infection that recorded $0 \%$ fruit decay. While mean percentages of the fungal decay for pectin and Newspaper were $2.22 \%, 3.7 \%, 4.44 \%$ and $2.22 \%, 3.7 \%, 3.7 \%$ sequentially with same plant.

Result current study using Polylastic acid, Pectin and Newspaper in cooperation with plant extracts recorded significant in fruit decay compared with result [9] and [10] which application of wrapping polyolefin film and Salicylic acid plus Calcium Chloride to reduce percentage of the decay fruits in Pomegranate (Punica granatum L.) and Kiwifruit (Actinidia deliciosa). Fruits stored using Polylactic acid, Pectin and Newspaper may be help to reduce levels of $\mathrm{O}_{2}$ and $\mathrm{CO}_{2}$ (reduce rate respiration) during improve modified atmosphere packaging (MAP), which could induce decreased microorganism proliferation with good permeability on the produce. This result is in agreement with studies carried out by [11] and [12], who used plant derivatives to improve atmosphere packaging (MAP) during storage fruit after harvest. Also, natural products (bioactive compounds) of the plant derivatives such as eugenol, phenolics and glycosides enhanced antifungal activity during prolonged [13] and [14]. 
Table 1. Effect of spraying plant extracts at concentration $5000 \mathrm{ppm}$ with wrap fruit using three type of the biodegradable materials (Polylactic acid (PLA), Pectin and newspaper) on fungal decay (\%) on the orange surface at $25^{\circ} \mathrm{C} \pm 2{ }^{\circ} \mathrm{C}$ and $\mathrm{RH} 65 \%-75 \%$ for 21 days.

\begin{tabular}{|c|c|c|c|c|c|}
\hline \multirow{2}{*}{ Treatments } & $\begin{array}{c}\text { Penicillium } \\
\text { digitatum }\end{array}$ & $\begin{array}{c}\text { Aspergillius } \\
\text { niger }\end{array}$ & $\begin{array}{c}\text { Fusarium } \\
s p\end{array}$ & \multirow[t]{2}{*}{ Mean } & \multirow[t]{2}{*}{${ }^{* *}$ Infection } \\
\hline & \multicolumn{3}{|c|}{ Damage (\%) } & & \\
\hline Pong-pong + PLA & $0.0^{\mathrm{a}}$ & $0.0^{\mathrm{a}}$ & $0.0^{\mathrm{a}}$ & $0.0^{\mathrm{a}}$ & Clean \\
\hline Chili + PLA & $0.0^{\mathrm{a}}$ & $0.0^{\mathrm{a}}$ & $0.0^{\mathrm{a}}$ & $0.0^{\mathrm{a}}$ & Clean \\
\hline Neem + PLA & $0.0^{\mathrm{a}}$ & $0.0^{\mathrm{a}}$ & $0.0^{\mathrm{a}}$ & $0.0^{\mathrm{a}}$ & Clean \\
\hline Lemon grass + PLA & $8.88^{\mathrm{b}}$ & $8.80^{\mathrm{b}}$ & $8.88^{\mathrm{b}}$ & $8.88^{b}$ & Slight \\
\hline Ginger+ PLA & $13.32^{\mathrm{b}}$ & $13.32^{\mathrm{bc}}$ & $13.32^{\mathrm{bc}}$ & $13.32^{\mathrm{bc}}$ & Slight \\
\hline Guazatine + PLA & $8.88^{\mathrm{b}}$ & $8.80^{\mathrm{b}}$ & $8.88^{\mathrm{b}}$ & $8.88^{\mathrm{b}}$ & Slight \\
\hline Untreated fruit & $15.54^{\mathrm{b}}$ & $17.77^{\mathrm{c}}$ & $17.77^{\mathrm{c}}$ & $17.02^{\mathrm{c}}$ & Moderate \\
\hline Pong-pong + Pectin & $2.20^{\mathrm{a}}$ & $2.22^{\mathrm{a}}$ & $2.20^{\mathrm{a}}$ & $2.22^{\mathrm{a}}$ & Trace \\
\hline Chili + Pectin & $2.20^{\mathrm{a}}$ & $4.44^{\mathrm{a}}$ & $4.44^{\mathrm{a}}$ & $3.7^{\mathrm{a}}$ & Trace \\
\hline Neem + Pectin & $2.20^{\mathrm{a}}$ & $4.44^{\mathrm{a}}$ & $6.66^{\mathrm{ab}}$ & $4.44^{\mathrm{a}}$ & Trace \\
\hline Lemon grass + Pectin & $8.80^{\mathrm{b}}$ & $8.84^{\mathrm{ab}}$ & $8.88^{\mathrm{ab}}$ & $8.88^{\mathrm{ab}}$ & Slight \\
\hline Ginger + Pectin & $11.10^{\mathrm{bc}}$ & $11.10^{\mathrm{ab}}$ & $13.32^{\mathrm{ab}}$ & $11.84^{\mathrm{bc}}$ & Slight \\
\hline Guazatine + Pectin & $6.60^{\mathrm{ab}}$ & $4.44^{\mathrm{a}}$ & $6.66^{\mathrm{ab}}$ & $5.92^{\mathrm{ab}}$ & Slight \\
\hline Untreated fruit & $17.77^{\mathrm{c}}$ & $15.5^{\mathrm{b}}$ & $17.77^{\mathrm{b}}$ & $16.29^{c}$ & Moderate \\
\hline Pong-pong + Newspaper & $2.22^{\mathrm{a}}$ & $2.22^{\mathrm{a}}$ & $2.22^{\mathrm{a}}$ & $2.22^{\mathrm{a}}$ & Trace \\
\hline Chili + Newspaper & $2.22^{\mathrm{a}}$ & $2.22^{\mathrm{a}}$ & $4.44^{\mathrm{ab}}$ & $3.70^{\mathrm{a}}$ & Trace \\
\hline Neem + Newspaper & $2.22^{\mathrm{a}}$ & $4.44^{\mathrm{a}}$ & $4.44^{\mathrm{ab}}$ & $3.70^{\mathrm{a}}$ & Trace \\
\hline Lemon grass + Newspaper & $6.66^{\mathrm{a}}$ & $4.44^{\mathrm{a}}$ & $6.66^{\mathrm{ab}}$ & $6.66^{\mathrm{a}}$ & Slight \\
\hline Ginger + Newspaper & $13.32^{\mathrm{ab}}$ & $6.66^{\mathrm{a}}$ & $13.33^{\mathrm{ab}}$ & $10.77^{\mathrm{ab}}$ & Slight \\
\hline Guazatine + Newspaper & $6.66^{\mathrm{a}}$ & $4.44^{\mathrm{a}}$ & $6.66^{\mathrm{ab}}$ & $5.92^{\mathrm{a}}$ & Slight \\
\hline Untreated fruit & $17.77^{\mathrm{b}}$ & $15.45^{\mathrm{b}}$ & $17.77^{\mathrm{b}}$ & $17.77^{\mathrm{b}}$ & Moderate \\
\hline
\end{tabular}

${ }^{*}$ Alphabets different in the same column show significant difference using Duncan's Multiple Range test $(\mathrm{P} \leq 0.05)$ and average was calculated from three replicates.

Severity of decay was visually evaluated during a spray to crude plant extract, at $28^{\circ} \mathrm{C} / 85 \% \mathrm{RH}$. The degree of infection on fruit was rated using a scale of 1 to 5, where 1-Clean, (0\%) infection; 2-Trace (1\% - 5\%) infection; 3-Slight (5\% - 15\%) infection; 4-Moderate (15\% - 30\%) infection; and 5-High (>30\%) infection. (Scale modified from Tzortzakis, 2006). Results presented in Figure 1 show different statistical analysis $(\mathrm{P} \leq 0.05)$ between fruit treated using Polylactic acid and those treated with plant extracts at $5000 \mathrm{ppm}$. The treatment using Polylactic acid with Pong-pong, Chili and Neem improved the quality of fruits under storage, and recorded best values in reducing the percentage of fungal decay, thereby completely preventing the growth of fungi on the surface of fruit. These treatments significantly outperformed $(\mathrm{P} \leq 0.05)$ other treatments and control. 


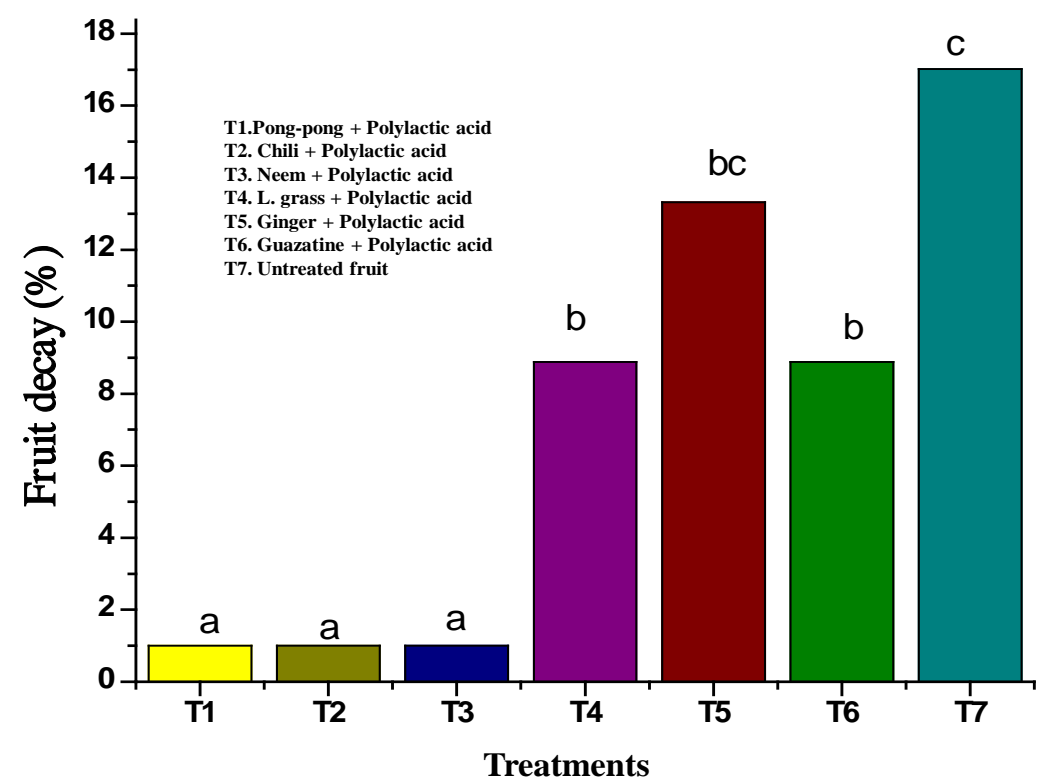

Figure 1. Observing the mean fruit decay of the fruit when wrapped with Polylactic acid wrapper and sprayed with different treatments and stored fruit in carton boxes at $25^{\circ} \mathrm{C} \pm 2{ }^{\circ} \mathrm{C}$ and $65 \%-75 \% \mathrm{RH}$ for 21 days. ${ }^{* *}$ Alphabets different in the same column show significant difference using Duncan's Multiple Range test $(\mathrm{P} \leq 0.05)$ and average was calculated from three replicates.

Untreated fruit (control) gave a mean fruit decay of $17.02 \%$, while lemon grass and Ginger recorded slight infection of $8.88 \%$ and $13.32 \%$ consecutively, but did not show any statistical difference with fungicide (Guazatine). The application of antimicrobial Polylactic acid (PLA) with spray plant extracts to improve the quality and shelf life of fruit has not yet been reported. However, a novel food-packaging concept has introduced a new generation of active biodegradable materials. This active packaging will restrict the growth of microorganisms and maintain food safety, even for non-sterile foods [15] and [16]. In a previous study [17] a bioactive thermoplastic film was successfully used to inhibition Penicillium sp, Aspergillus niger and Sclerotinia sclerotiorum growth. Polyvinyl alcohol (PVA, CGP and PVA) has been combined with natural polymers in many biomaterial applications to save foods and inhibition growth microbiology [18] and [19].

The effect of packaging fruit, after spraying plant extract on its surface and wrapping it using pectin tissue is shown in Figure 2. Statistical analysis $(\mathrm{P} \leq$ 0.05 ) showed that wrapping the fruit using pectin tissue along with spraying Pong-pong, Chili and Neem extracts were the best treatments and showed significant decrease (Trace) in infection on surface fruit with $2.22 \%, 3.7 \%$ and $4.44 \%$, respectively. Results showed light infection (5.92\%) when using treatment from pectin with Guazatine. Also, Lemon grass and Ginger showed noticeable effect (slight) on the spread of infection in fruit stored, giving mean fruit decay values of $8.88 \%$ and $11.8 \%$. The untreated fruit wrapped using pectin tissue showed moderate infection and demonstrated high values (16.29\%) of fruit decay. 


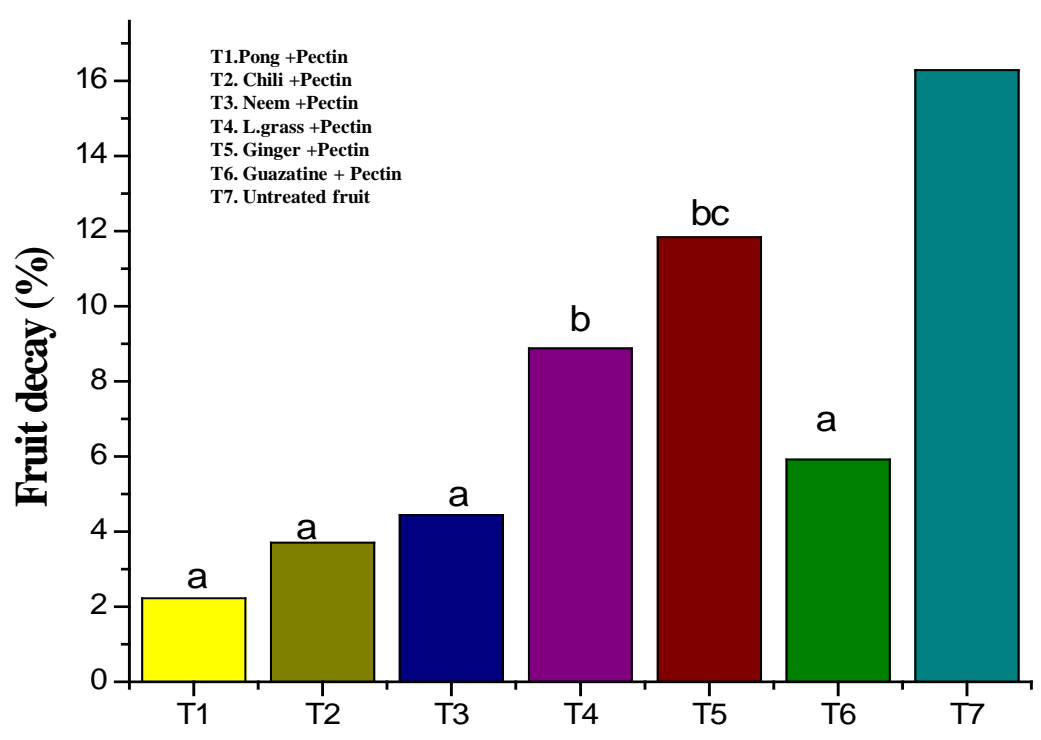

Treatments

Figure 2. Observing the mean fruit decay of the fruit when wrapped with pectin wrapper and sprayed with different treatments and stored fruit in carton boxes at $25^{\circ} \mathrm{C} \pm 2^{\circ} \mathrm{C}$ and $65 \%-75 \% \mathrm{RH}$ for 21 days.

The post-harvest treatment of wrapping fruit using newspaper and the spraying of plant extracts demonstrated significant differences in fruit decay (Figure 3). Packaging fruits with News Paper and the spraying of extracts from Pong-pong, Chili and Neem decreased infection percentage (fruit decay). All treatments reduced fungi growth on fruits surface to Chili and Neem respectively. Minimal levels (Trace) and recorded values of $2.22 \%, 3.70 \%$ and $3.70 \%$ for Pong-pong. On the other hand, the maximum fruit decay shown in untreated fruits was $17.77 \%$. Treating fruits with Lemon grass and Ginger were improved the quality of fruits by decreasing infection to $6.66 \%$ and $10.77 \%$ respectively causing the degree of infection to be slight.

The application of antimicrobial pectin and newspaper wrapping along with plant extracts in fruit decontamination has not yet been reported. However result current result come better of result [20], that evaluated Bio Save 10 LP and $\mathrm{SO}_{2}$ for their efficacy in controlling mycelia spread and sporulation of Muscadine grape during storage. The fruits were stored in emanating sheets, and removed bi-weekly up to 4 -weeks $\left(0^{\circ} \mathrm{C}-1^{\circ} \mathrm{C}, 90 \%\right.$ to $\left.95 \% \mathrm{RH}\right)$. It was found that treatment reduced molds, and improved overall fruit quality when compared to the untreated fruits. Furthermore, [21] reported that wrapping fruit with different types of the papers (white paper, brown paper, tissue paper and newspaper) inhibitions growth microbiology and improves post-harvest quality.

\subsection{Weight Loss (\%)}

Data of ANOVA $(\mathrm{P} \leq 0.05)$ as shown in Table 2 points to weight loss in stored fruit. This is a clear variation from other treatments. The average weight loss was faster for untreated fruits compared to treated fruits. Generally, all the 


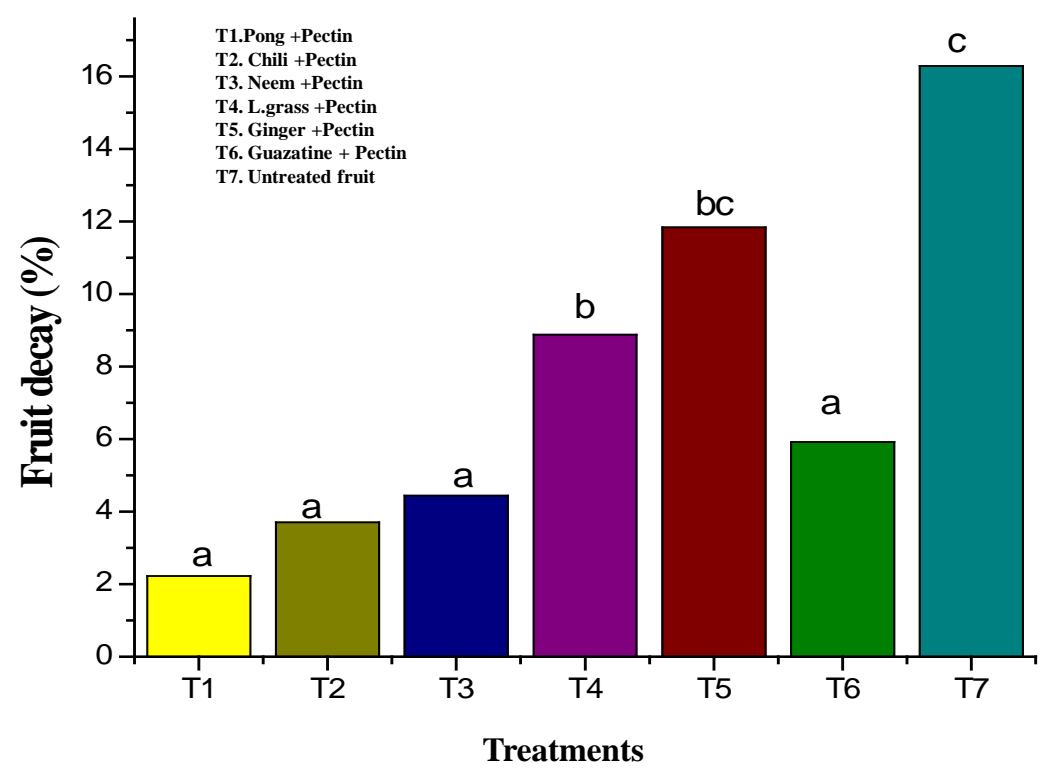

Figure 3. Observing the mean fruit decay of the fruit when wrapped with Newspaper wrapper and sprayed with different treatment and stored fruit in carton boxes at $25^{\circ} \mathrm{C} \pm 2^{\circ} \mathrm{C}$ and $65 \%-75 \% \mathrm{RH}$ for.

Table 2. Effect of fruit wrappings and spray plant extracts on the physiological weight loss (\%) of orange fruits during storage at $25^{\circ} \mathrm{C} \pm 2{ }^{\circ} \mathrm{C}$ and $65-75 \mathrm{RH} \%$ for 21 days.

\begin{tabular}{ccccc}
\hline \multirow{2}{*}{ Plant extracts } & \multicolumn{3}{c}{ Biodegradable materials (Wrapping) } \\
\cline { 2 - 5 } & Polylactic acid & Pectin & News paper & Mean \\
\hline Pong-pong & $3.7^{\mathrm{a}}$ & $5.55^{\mathrm{a}}$ & $8.30^{\mathrm{a}}$ & $5.87^{\mathrm{a}}$ \\
Chili & $4.2^{\mathrm{b}}$ & $6.60^{\mathrm{b}}$ & $8.9^{\mathrm{b}}$ & $6.56^{\mathrm{b}}$ \\
Neem & $4.88^{\mathrm{c}}$ & $8.4^{\mathrm{c}}$ & $9.7^{\mathrm{c}}$ & $7.66^{\mathrm{c}}$ \\
Lemon grass & $6.15^{\mathrm{d}}$ & $9.9^{\mathrm{d}}$ & $10.8^{\mathrm{d}}$ & $8.95^{\mathrm{d}}$ \\
Ginger & $7.2^{\mathrm{e}}$ & $9.9^{\mathrm{d}}$ & $11.4^{\mathrm{e}}$ & $9.5^{\mathrm{e}}$ \\
Untreated & $9.82^{\mathrm{f}}$ & $12.76^{\mathrm{e}}$ & $13.4^{\mathrm{f}}$ & $11.99^{\mathrm{f}}$ \\
\hline
\end{tabular}

${ }^{*}$ Data in columns (Biodegradable materials) and raw with different letters are statistically different according to Duncan's multiple range tests $(\mathrm{P} \leq 0.05)$ and all treatments consisted of three replicates.

treatments improved the fruits quality including decreasing weight loss. Wrapping fruit with polylactic acid exceeded Pectin and Newspaper in reducing weight loss after 21 days of storage. It recorded values of $3.77 \%, 4.2 \%, 4.88 \%$, $6.15 \%$ and $7.2 \%$ each for Pong-pong, Chili, Lemon grass and Ginger respectively. Conversely, fruits treated with the plant extracts and then packaged using Newspaper wraps recorded percentage of weight loss (8.30\%, 89\%, 9.7\%, 10.8\% and $11.4 \%)$. The reduction of weight loss may be due to improved storage conditions during modified atmosphere packaging (MAP), which increases relative humidity, thereby reducing respiration rates and fungal decay. Furthermore, plant extracts inhibition growth fungal on surface stored fruit by creating a thin film of extracts surrounding the fruit, which modifies the microclimate of the fruits. 


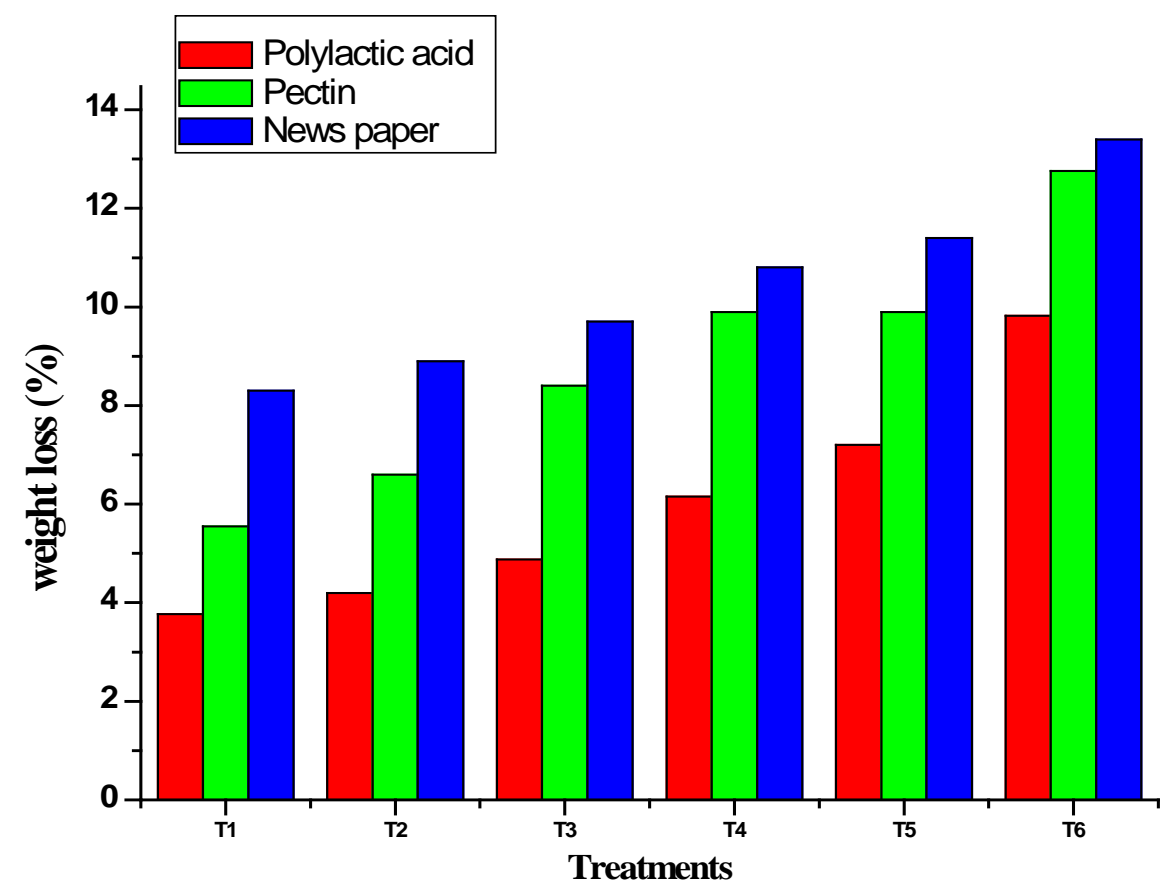

Figure 4. Effects of combining Polylactic acid, Pectin and Newspaper with sprayed plant extracts on percentage weight loss (\%) of stored samples at $25^{\circ} \mathrm{C} \pm 2^{\circ} \mathrm{C}$ and $65 \%-75 \%$ for 21 days. T1. Pong-pong, T2. Chili, T3. Neem, T4. Lemon grass, T5. Ginger, T6. Untreated fruit.

These results are in agreement with previous studies [22] and [23] that used oil and plant extracts to decrease weight loss of fruit stored with different concentrations.

From ANOVA table at $\mathrm{P} \leq 0.05$ and Figure 4 result showed that Pong-pong statistically outperformed the other plants in lowering weight loss by $5.87 \%$. Likewise, extracts of Chili, Neem, Lemon grass and Ginger differed statistically $(6.56 \%, 7.66 \%, 8.95 \%$ and $9.5 \%)$ while the untreated fruits had the highest value (11.99\%). The current study recorded decrease in percentage of weight loss in stored fruit compared with findings of [24] [25] and [26], that used protective chemicals (polyethylene)to effectively control compositional changes by delaying the ripening process, leading to minimum quality loss above 3 weeks of storage at ambient temperature.

The increased shelf life of fruit could be due to the presence of physical barrier in gas diffusion through fruit stomata by which gas exchange takes place between internal tissues and external atmosphere. The lack of diffusion reduced respiratory rate and loss of water, thereby resulting in increased shelf life. These results support the works [11] and [27], which demonstrated the inhibition of fungal growth by plant extracts on fruits surface.

\section{Conclusion}

Wrapping-treated citrus fruit with extracts of plant led to increasing shelf life and improving fruit quality under room condition $(25 \pm 2)$ storage. Modified 
atmosphere packaging using biodegradable materials can be as a potential to replace commercial chemicals for citrus packaging with more future researches.

\section{References}

[1] Lofts, S. (2011) Prediction of Accumulation and Leaching of Fungicide Copper in Agricultural Soils. NERC/Centre for Ecology and Hydrology, Lancaster, $58 \mathrm{p}$.

[2] Behnaz, S., Sadrollah, R., Majid, R. and Mohammad, J. (2009) Biological Control of Postharvest Disease Caused by Penicillium digitutum and P. italicumon Stored Citrus Fruits by Shiraz Thyme Essential Oil. Advances in Environmental Biology, 3, 249-254.

[3] Pal, K.K. and McSpadden, G.B. (2006) Biological Control of Plant Pathogens. The Plant Health Instructor.

[4] Williams, R. (2009) Control of Carob Moth (Ectomyelosis ceratonia) in Fresh Dates Fumigated with ProFume. Presentation at 2009 MBAO, San Diego, 10-12 November 2009.

[5] Barkai-Golan, R. (2011) Postharvest Diseases of Fruits and Vegetables Development and Control. Elsevier, Amsterdam.

[6] Pramila, N.K., Dubey, A. and Shukla, K. (2008) Use of Some Essential Oils as Post-Harvest Botanical Fungicides in the Management of Grey Mould of Grapes Caused by Botrytis cinerea. World Journal of Microbiology and Biotechnology, 24, 39-46. https://doi.org/10.1007/s11274-007-9435-2

[7] Tzortzakis (2006) Maintaining Postharvest Quality of Fresh Produce with Volatile Compounds. Innovative Food Science and Emerging Technologies, 8, 111-116. https://doi.org/10.1016/j.ifset.2006.08.001

[8] Tune, S., Chollet, E., Harlier, C.P., Preziosi-Belloy, L. and Gontard, N. (2007) Combined Effect of Volatile Antimicrobial Agents on the Growth of Penicillium notatum. International Journal of Food Microbiology, 113, 263-270. https://doi.org/10.1016/j.ijfoodmicro.2006.07.004

[9] Kazemi, M., Aran, M. and Zamani, S. (2011) Effect of Calcium Chloride and Salicylic Acid Treatments on Quality Characteristics of Kiwifruit (Actinidiadeliciosa cv. Hayward) during Storage. American Journal of Plant Physiology, 6, 183-189. https://doi.org/10.3923/ajpp.2011.183.189

[10] Nazmy, A., Samah, I. and Hassan, M. (2012) Effects of Polyolefin Film Wrapping and Calcium Chloride Treatments on Postharvest Quality of "Wonderful" Pomegranate Fruits. Journal of Horticultural Science and Ornamental Plants, 4, 7-17.

[11] Serrano, M., Martinez-Romero, D., Castillo, S., Guillén, F. and Valero, D. (2008) The Use of the Natural Antifungal Compounds Improves the Beneficial Effect of MAP in Sweet Cherry Storage. Innovative Food Science \& Emerging Technologies, 6, 115-123. https://doi.org/10.1016/j.ifset.2004.09.001

[12] Valero, D., Valverde, J.M., Martínez-Romero, D., Guillén, F., Castillo, S. and Serrano, M. (2006) The Combination of Modified Atmosphere Packaging with Eugenol or Thymol to Maintain Quality, Safety, and Functional Properties of Table Grapes. Postharvest Biology and Technology, 41, 317-327.

https://doi.org/10.1016/j.postharvbio.2006.04.011

[13] Calvo, A.M., Wilsonm, R.A., Bok, J.W. and Keller, N.P. (2002) Relatioship between Secondary Metabolism and Fungal Development. Microbiology and Molecular Biology Reviews, 66, 446-459. https://doi.org/10.1128/MMBR.66.3.447-459.2002

[14] Rahman, M.D.A., Paul, P. and Rahman, A.A. (2011) Antinociceptive, Antibacterial 
and Diuretic Activities of Cerbera odollam Gaertn Roots. Research Journal of Pharmaceutical, Biological and Chemical Sciences, 2, 16-23.

[15] Lee, M.W., Han, S.O. and Seo, Y.B. (2008) Red Algae Fiber/Poly(Butylenes Succinct) Biocomposites: The Effect of Fiber Content on Their Mechanical and Thermal Properties. Composites Science and Technology, 68, 1266-1272. https://doi.org/10.1016/j.compscitech.2007.12.016

[16] Srinivasa, P.C., Ramesh, M.N., Kumar, K.R. and Tharanathan, R.N. (2003) Properties and Sorption Studies of Chitosan-Polyvinyl Alcohol Blend Films. Carbohydrate Polymers, 53, 431-438. https://doi.org/10.1016/S0144-8617(03)00105-X

[17] Silva, B.D.S., Ulhoa, C.J., Batista, K.A., Yamashita, F. and Fernandes, K.F. (2011) Potential Fungal Inhibition by Immobilized Hydrolytic Enzymes from Trichoderma asperellum. Journal of Agricultural and Food Chemistry, 59, 8148-8154. https://doi.org/10.1021/jf2009815

[18] Tripathi, P. (2010) Biological and Biorationals in the Management of Agricultural Insect Pests: An Eco-Friendly Approach. In: Arya, A. and Monaco, C., Eds., Seed Borne Diseases: Ecofriendly Management, Scientific Publishers, Jodhpur, India, 171-189.

[19] Silva, B.D.S., Ulhoa, C.J., Batista, K.A., et al. (2012) Biodegradable and Bioactive CGP/PVA Film for Fungal Growth Inhibition. Carbohydrate Polymers, 89, 964-970. https://doi.org/10.1016/j.carbpol.2012.04.052

[20] MacLean, D. (2011) BioSave 10-LP and $\mathrm{SO}_{2}$ for Postharvest Control of Muscadine Pathogens. Annual Conference, Waikoloa, Hawaii, 25-28 September 2011, 21-30.

[21] Roy, M., Rahim, A. and Alam, M.S. (2011) Effect of Wrapping Papers on Physiological Changes and Shelf-Life of Mango cv. Langra. Journal of Environmental Science and Natural Resources, 4, 99-103.

[22] Arvanitoyannis, I.S. (2010) Irradiation of Food Commodities: Techniques, Applications, Detection Legislation, Safety and Consumer Opinion. Academic Press, Cambridge, MA, 763.

[23] Ibtesam Badawy, F.M., Nashwa Sallam, M.A., Ibrahim, A.R. and Asran, M.R. (2011) Efficacy of Some Essential Oils on Controlling Green Mold of Orange and Their Effects on Postharvest Quality Parameters. Plant Pathology Journal, 10, 168-174. https://doi.org/10.3923/ppj.2011.168.174

[24] Hayat, I., Masud, T. and Rathore, H.A. (2005) Effect of Coating and Wrapping Materials on the Shelf Life of Apple (Malus domestica cv. Borkh). International Journal of Food Safety, 5, 24-34.

[25] Ishaq, S., Rathore, H.A., Masud, T. and Ali, S. (2009) Influence of Post Harvest Calcium Chloride Application, Ethylene Absorbent and Modified Atmosphere on Quality Characteristics and Shelf Life of Apricot (Prunus armeniaca L.) Fruit during Storage. Journal of Nutrition, 8, 861-865.

[26] Rathore, H.A., Masud, T., Sammi, S. and Majeed, S. (2009) Effect of Polyethylene Packaging and Coating Has Fungicide, Ethylene Absorbent and Antiripening Agent on the Overall Physico-Chemical Composition of Chaunsa White Variety of Mango at Ambient Temperature during Storage. Pakistan Journal of Nutrition, 8, 1356-1362. https://doi.org/10.3923/pjn.2009.1356.1362

[27] Samra, N.R., Mansour, A.M., Tourky, M.N. and Tarabih, M.E. (2006) Pre and Post Harvest Treatments on Peach Fruit Grown under Desert Conditions. Journal of Agricultural Science, 31, 7835-7846. 